\title{
What Would Jesus do in a Distance Learning Mode of Teaching?
}

\author{
Maja Seguin \\ Evangelical Theological Seminary, Osijek \\ maja.seguin@evtos.hr
}

UDK: 2-75:27-246:37.091.3

Professional paper https://doi.org/10.32862/k.15.1.3

\begin{abstract}
Several pedagogical considerations come with the transition from traditional to virtual teaching, and it is necessary to provide teachers with a potential approach to teaching and learning. This article gives an overview of the teaching methods Jesus used with a focus on parables, highlights the modern constructivist approach to teaching, and singles out characteristics of constructivism in Jesus' teaching model. Combined, this presents a basis for practical advice in today's context of online teaching, respectively in a virtual setting. The article highlights characteristics of Jesus as a teacher which present-day teachers can apply to their contexts and finishes with suggestions for further research.
\end{abstract}

Keywords: parable, constructivist approach to teaching, distance (online) teaching, online learning

\section{Introduction}

In the last year, more than ever, teachers taught remotely, using the Internet and various applications. The need for the rapid mastery of the necessary technical skills and adaptation to virtual classrooms and tasks has become very obvious and real. Theological institutions, including biblical schools, are faced with an even greater challenge, as part of their curriculum includes an aspect of fellowship that is realized in direct contact with others. Classrooms and common spaces have been replaced by virtual ones, and teachers faced the challenge in which they seek 
to pass on knowledge, skills, abilities, and values that can be linked to students' daily experiences. All of this requires certain teacher competencies in their approach to teaching.

This article aims to outline the main teaching model (Hultgren 2000,1) that Jesus used parables, explain the constructivist approach to the learning process, list the characteristics of the constructivist approach to the learning process in Jesus' teaching model, and give practical advice for teaching in today's circumstances where teachers are forced to teach remotely. This can help us see how contemporary teachers can follow Jesus' example in their remote teaching efforts.

The paper will not deal with the precise definition of the model of Jesus' teaching, the specific number of uses of the method, linguistic aspects, or theological interpretations, but it will try to answer the questions of whether there is something from Jesus' teaching that we could apply in our contemporary classrooms, and what characteristics could be replicated in today's context. The aim of the paper is not to contribute to the interpretation of parables, but to draw a few key characteristics about the way Jesus taught, about the character he imparted to his students, and what we could, as teachers in a contemporary and digital context, impart to our students. Also, the aim of this paper is not to claim that Jesus taught remotely, nor to point out the superiority of the virtual or the inferiority of the traditional approach to learning, and vice versa.

\section{Jesus' Model of Teaching}

\subsection{Jesus - the Teacher}

Of the forty titles that describe Jesus, the Gospels highlight the one that describes him as a "teacher" (Stein 1978, 1). He differed in many ways from the rabbis of his time, from the way he taught, the content of his teaching, the places he taught, to the bond with his students, including the relationship towards the marginalized (Stein 1978, 2). Although he did not use the modern aids available to today's teachers, he managed to gain the attention of his listeners. Sometimes he was too popular and his lectures attracted crowds and as a teacher, he had to teach from a boat (Mk. 4:1). The crowds were attracted not only by what Jesus taught them but also by what he was like.

Stein $(1978,8)$ states that Jesus had authority, gave a message accompanied by miracles and signs, and he had his particular kind of stylistic methods, although these methods and the ways he taught did not represent the scientific approach we request and expect from our students today. In his teaching, he used the following figures of speech - exaggeration, overstatement, riddles, comparisons and parabolic stories, metaphorical sayings, proverbs, paradoxes, rhetorical arguments, 
irony, questions, and poetic parallelism, some of which are used in the synoptic gospels to recognize a parable (Hultgren 2000,2) relevant to this paper. In his time and context, Jesus is an innovative teacher when he uses parables. There are no parables in rabbinic literature before the time of Jesus (Jeremias 1972, 12; Porton 2006, 207), nor in Middle Eastern and Greco-Roman literature (Schottroff 2006, 105) that are reminiscent of Jesus' in their content and function. His teaching, his parables, differs from the teachings of his predecessors, contemporaries, and successors (Breech 1989, 24).

The section that follows discusses one stylistic method that Jesus used in his teaching, that of the parable. The parable as a figure of speech in the paper will not differ much from other figures of speech that could also be interpreted by the same term. Thus, in this paper, the parable is discussed in a very broad sense.

\subsection{Jesus' Use of Parables}

The most striking, the most influential (Snodgrass 2008, 1) and widespread expressions are the parables or illustrative stories, which Jesus used. The narrative of the parable is pictorial and tells a fictional story with the application (Schottroff 2006 , 103). Jesus was a perfect creator of stories, with which he captured attention, encouraged, instructed, and occupied. Stories are thought-provoking and stimulating, but they are also the fastest learning tool (Snodgrass 2008, 1). Full of illustrative figures, stories leave a deeper impression on the mind than abstractions (Jeremias 1972, 11) because the listener can find himself in familiar and understandable circumstances. But Jesus' parables provide an extended analogy with comparisons and establish a rhetorical point (Snodgrass 2008, 2). They can be experienced as vivid moral lessons suitable for younger ages, but also as the armed speech of a politician in a fierce campaign (Hunter 1979, 9).

The word parable is a loanword from the Greek language whose meaning refers to the "comparison" by which Jesus in his teaching compared eternal realities with those common and everyday experiences of that time (Hultgren 2000, 2). Snodgrass $(2008,7)$ warns that parables are more than stories, and although they contain elements of eschatology, they are focused on life on earth. Through parables, Jesus taught from life experiences and the environment in which he found himself, improvised rather than elaborated, in a lively encounter with people (Hunter 1979, 12), and he taught about the coming of the kingdom of God (Mk. 1:14-15, Mt. 4:23, Lk. 4:42-43), about his Father God, and about important ethical principles according to which we should strive to be like God (Snodgrass, 2008, 2). Jesus' parables radically teach about the Kingdom, political and sociopolitical topics, and thus represent "works of art and weapons," which bring lessons to some and insults to others (Snodgrass 2008, 2), moreover because they mainly depict something arising from conflict, from justification to attack (Jeremias 1972, 
21). Schottroff $(2006,103)$ points out that the narrative of the parable does not describe a historical event, but expounds on a kind of structure and mutual social relations, for example, the colored extremes of the injustice of the rich and the suffering of the poor. Jesus spoke fiction, which was understood to be true because listeners could envisage it in their context (Breech 1989, 60).

To the question of why Jesus used parables, it is possible to give different answers: a) to illustrate his teaching and thus evoke the intellectual understanding and comprehension that comes from listening to the voice of God (Schottroff 2006, 105); b) to conceal the full meaning of his message from those who might misinterpret a lesson out of incorrect and political motives; c) so that he could "disarm" his listeners' arguments (Stein 1978, 42). But Jesus does not use his parables in terms of philosophical argumentation or a rhetorical upgrading of principles, because in his teaching he does not require from his disciple's prior knowledge other than what they have already experienced in life (Hultgren 2000, 9). Parables are a model of polemical teaching, in which Jesus compares the unknown with the known, and the strange with something more familiar (Hunter 1979, 10).

Although Jesus' original listeners were not Christians and his teaching was especially valuable as a tool for teaching secular audiences (Jones 1999, 6), Jesus taught in parables that were inclusive, proactive, calling for a stand on Jesus' identity and mission (Jeremias 1972, 30). Parables require the active participation of the listener, but also a response in the form of an attitude or accompanying action, which should reflect a correct understanding of the lesson taught (Schottroff $2006,104)$. In this way, they challenge the verdict or call for an answer, frequently by and through questions like 'What do you think?' (Hunter 1979, 12). Hultgren $(2000,8)$ observes that in his parables Jesus directly addresses his listeners with penetrating questions ("Which one of you?", "What woman?", "Who among you?"...). Such introductions immediately intrigue listeners, make them a part of the lesson, and demand an answer. The answer is that obligatory part of the lesson and is sought through many rhetorical questions or an open conclusion in the parables of Jesus. Hunter understands the purpose of the parable as "seeing, judging, acting" (Hunter 1979, 13). Bailey $(1983,40)$ found three parts in each parable; the narrative, the response in terms of acting or accepting a new understanding of God's way with people, and the reflection on theological messages that underline the student's response. But Jesus' model of teaching reveals to us the model and character of the teacher. The following section highlights some of the character traits of the teacher, which can also serve us in our efforts to replicate the role model in the teaching approach. 


\subsection{Jesus' Model of Teaching Reveals the Character of the Teacher}

Through his parables, Jesus shows that he knows his disciples well - he knows their context and customs (Schottroff 2006, 118). Jesus is not interested in the class division, moreover, he shows a personal interest in the individual and does not give place to pride and complacency in his actions. In his teaching and actions, he is very relational and demands that the learned be applied in relationships and reflected in the way we look and act towards others. So he allows the sinner to kiss and wash his feet with tears and hair, and he teaches Simon to change his attitudes. Jesus pays special attention to the "problematic," to those who have no recognized success and who are not accepted in their environment, to the smallest, the lost, and the last such as the lost coin and the lost sheep (Hunter 1979, 56).

Furthermore, he knows the rhetorical principles of effective presentation and uses anecdotal rules - the rule of contrast, the rule of a story with three characters (the three passers-by in the story of the Good Samaritan, the three excuse-makers in the story of the Great Supper, the three servants in the story of the talents), and the rule of stressing or spotlighting the last character or action in the story (Hunter 1979, 12). Jesus does not use indirect speech in his narrative discourse and thus makes the characters he speaks of in the present (Breech 1989, 68). Jesus speaks of the subject matter with knowledge and confidence (Hunter 1979, 57) and authority. Breech $(1989,67)$ has not noticed any other narrator in Western antiquity who speaks with such authority solely based on his "imaginative capacity to select and to order reality." At the same time he reminds his listeners that God himself does not treat everyone based on strict justice, and although at times his lessons seem unfair, they are certainly part of his will which is marvelous. This element of surprise at the end of many of his parables speaks to the unexpected behavior of the character in the story, by which he teaches what God is like (Hultgren 2000, 10). Such endings are intriguing also because his parables do not provide insight into the outcome of the situation, Jesus does not give a complete answer, and therefore Jesus teaches by "restor[ing] to our consciousness an awareness of a genuine ambiguity in the actions of characters" (Breech 1989, 29), simultaneously not intervening by approving or reprobating these actions (Breech 1989, 53).

The supporting characters, those in Jesus' parables who do not have stories, have an explanation for their actions, while the actions of his main characters are not supported by a motive, they are simply "active catalysts of events" that trigger the actions of other characters (Breech 1989, 71). As a teacher, he does not use abstract concepts, attributional descriptions, or theological discussions, but depicts and brings God closer through the language of concrete metaphors (Hultgren 2000, 10). He arouses hope and optimism with its content (Jeremias 1972, 120). According to Lambrecht $(1974,129)$, Jesus does not try to be right with parables, 
but wants to gain the listener, does not want to defeat the opponent but to win them over, while Jones $(1999,40)$ points out that Jesus himself was the unique parable of God, incarnating "freedom and love and forgiveness and compassion," the exemplar of self-giving love by identifying with the alienated. Jesus is an endless parable, and "[1]ike the characters in his parables, Jesus lives in a story without end” (Breech 1989, 78).

Jesus used experiential parables to transfer his eternal teaching into the disciples' daily lives. In this pedagogical approach, Jesus was a constructivist, he approached learning as an active process, realized in the natural environment, through experience. His lesson had to be understood and personalized by each listener, and this included previously acquired knowledge and experience which would then be upgraded in the process of critical thinking. These are the elements of a constructivist approach to learning, which is explained in the next section.

\section{Jesus' Model of Teaching and Elements of Constructivism}

\subsection{A Constructivist Approach to Learning}

Contrary to the behaviorist, and as an upgrade of the cognitivist approach to the learning process, there is the constructivist approach (Jukić 2013, 243). Jukić explains the constructivist approach as being based on the active and constant constitution of knowledge, development, and creation of values and beliefs through new problems (situations), in other words building personal knowledge which creates reality. This is a learning process in which the student's prior knowledge and skills are upgraded by creating new insights over existing personal conceptual insights when encountering new information (Robertson 2008, 2). In such a learning process, the meaning is created, new understanding and knowledge are actively built, while previous understanding is constantly assessed, in other words through the interaction of past experiences with new information. Characteristics of constructivism include learning through social interaction, communicating with the environment, gaining experience and understanding through language and culture in which new knowledge acquires its meaning in contact with previous experience.

Robertson $(2008,2)$ points out that this is a five-phase approach, known as the 5 E learning model, with phases: Engagement, Exploration, Explanation, Elaboration, and Evaluation. Through an engaging introduction, students are engaged in what needs to be learned, thus they are being stimulated with enthusiasm and connected with a particular problem (situation) and directed to start looking for a solution. An engaging phrase creates curiosity and activates critical thinking through real and student-familiar topics. The exploration phase gives students 
space to create an experience from which to learn, especially through researching a social problem in a real-world situation, by drawing a conclusion from the problem and connecting it with tangible reality. Students at this stage are completely absorbed by the problem they are trying to solve on their own. The formation of the explanation phase allows for the analysis and interpretation of the concept being researched, helps students develop skills and attitudes in learning, and allows the teacher to present terms and definitions and guide the learning process. The phase of elaborating and confirming the knowledge gained through experience is intended to expand existing knowledge and put that knowledge into function in a meaningful context. In the final phase, the evaluation phase, students and the teacher can evaluate the understanding of new knowledge and skill development.

\subsection{Jesus - a Constructivist}

If we reflect again on Jesus' use of parables, we can say how Jesus enabled his listeners, with his inclusive parables, to be part of his teaching and connect with his message. Parables often represented a problem that students needed to explore to learn the truth from it. Jesus thus encouraged the exploration of social issues and relationships in the context, language, and customs that were familiar and proximate to the disciples. Using parables, Jesus directed the disciples to explore and seek answers to their questions. Through the stories he used, Jesus taught the disciples in context and allowed them to gather explanations for themselves, and afterward explained the content of his teaching to them. Jesus did not evaluate his disciples through tests, but he could assess them through their ability to analyze, connect, and apply in practice what they learned.

Jesus' teaching model is an example of non-traditional teaching, what we call a constructivist approach today, by applying old and new ideas, using relevant representations, questioning students, leaving some questions unanswered, speaking with love and respect, promoting critical thinking, and teaching through examples (Roso 2010, 43).

\section{Constructivist Characteristics in Distance (Online) Learning}

\subsection{Distance Learning}

Although used, revolutionized, and current in contemporary education, distance learning has a history dating back to the $19^{\text {th }}$ century, when correspondence teaching enabled education for the marginalized (Katavić et al. 2018, 96). Lee (2017, 16) points out that it may be impossible to agree on a clear definition of distance learning, but today we generally think of it as the narrower category of online 
(virtual) learning, by using computers as a communication medium to transmit educational content, establish communication between students and teachers and maintain the entire teaching process. The most frequently mentioned feature of online learning is flexibility, because virtual learning in today's circumstances is not only necessary, but also a model that provides access to education at any time and any place (Means et al. 2009, 1).

As early as the late 1990s, Bonk and Dennen $(1999,5)$ pointed to possible challenges that arise from the pressure to change the teaching and technological expectations of teachers and students as they move from traditional to virtual teaching. For example, teacher's preparations take much longer and require a different approach, and students are also required to have certain skills and technological literacy. But they also explain that the virtual world is an intriguing place to experiment and rethink one's approach to teaching. We can say that online learning is an opportunity to "develop self-governing learners," but it also allows for a collaborative approach to agreeing about the meaning and a mutual establishment of understanding (Garrison 2009, 95).

Virtual education arose from computer conferencing and converged with a constructivist approach to learning (Garrison 2009, 97) because of its efforts to change passive pedagogical methods, retain students' attention and involvement through time and collaborative learning content (Garrison 2009, 93). However, online learning in Croatia is still only a secondary alternative approach to traditional teaching, with its development slowed by cultural and political, not just technological factors, but at the same time, it is a necessary approach in circumstances when access to educational resources is limited and when the aim is to improve the quality of education (Katavić et al. 2018, 98). What Katavić et al. argue, supporting the constructivist approach in Jesus' way of teaching, is that online learning allows content to be visualized more effectively. Jesus customized his teaching content according to the needs of his students and taught them how to learn, just as the contemporary online classroom requires such teachers in their approach to learning and teaching (Katavić et al. 2018, 101). Furthermore, as online learning seeks to access content more effectively, it has the feature of implementing learning outcomes through critical discourse in shared teaching efforts, and this requires a structured leadership approach that purposefully steers toward meaning and understanding (Garrison 2009, 98). And that is exactly what Jesus demonstrated in his approach to all that he taught.

However, on the one hand, there are shortcomings of online learning that are technical and logistical, as well as in a personal attitude of frustration and lack of interest (Katavić et al. 2018, 97), while on the other hand there is research showing that virtual learning creates stronger learning outcomes in students rather 
than learning exclusively in the traditional frontal approach (Means et al. 2009, 18 ), and added that using both models in teaching achieves stronger learning outcomes than is accomplished exclusively by the traditional approach (Means et al. $2009,19)$. Swan $(2005,8)$ states that there are also studies that indicate that online learning supports conceptual learning more than traditional methods. A virtual environment enables the creation of an aspect of social presence and a learning community in which there is a joint creation of effective critical thinking (Swan et al. 2009, 43).

\subsection{Constructivism in Online Learning}

The constructivist approach is also expressed in the view that abstract ideas can be presented using computers in a concrete and understandable form and be more easily connected with existing knowledge, can examine current mental constructions and bring about changes in knowledge, or eliminate misconceptions (Swan 2005 , 3). Swan $(2005,5)$ emphasizes that online learning is worth consideration precisely because learning does not take place exclusively within the mind, but at the social level with the help of tools and cultural artifacts.

The Internet offers a space for a mentoring relationship with students and so all tasks, advice, and feedback can be individualized and timely. In line with the constructivist approach, when virtual content is properly presented; presentations, discussions, and argumentation of articles can help students to adopt new concepts meaningfully by connecting with previously acquired experiences (Bonk and Dennen 1999, 12). Also, the role of the teacher in such an environment comes to the fore in terms of a guide or facilitator rather than a lecturer, when in teaching activities s/he can opt for those activities which encourage the student's areas of interest and strength. In this way, students can be encouraged to independently explore and think critically about the importance of contributing to the learning process and accompanying action. Contrary to the traditional approach in the classroom where passive students are taught, in the virtual classroom, they can become active participants who build meaning and gain new knowledge together with others. Constructivism in online learning gives us space to reflect on teaching theories and pedagogical approaches by which we want to move away from the mere transfer of knowledge to the place where teachers and students create knowledge together (Fitzpatrick et al. 2009, 15). And in the virtual environment, we can reflect on the character of Jesus and his approach, whose elements we find in the contemporary constructivist approach, and we can encourage student creativity, active participation, critical thinking, and research, as well as finding new knowledge that encourages real action. 


\section{Application}

Most of Jesus' teaching was delivered close to his disciples and listeners. He was a teacher who liked to be close to those he taught, although at times he had to teach away from the crowd, for example from a boat. Jesus was a different teacher, differing from others - he used innovative methods, he taught outside places intended for teaching, he had authority and a character that attracted many listeners. His method of teaching was a story with a lesson, which required a certain answer an attitude or accompanying action. He taught real, deep, and contextual lessons. His teaching called for application and change. His method of teaching had for goal to encourage listeners to think hard, unlike stories by which contemporary teachers want to spice up their somewhat dry presentation, but to challenge commitment and determination. In his teaching, Jesus practices a more radical message that attracts disciples, changes their attitudes, and makes them take on his example and follow him. It is clear that in all his teachings, Jesus believes that his listeners, marked with flaws and weaknesses, can be signposts to God's rule and in their care and action can understand the deeper care and action of God (Hunter 1979, 14).

The theme of Jesus' teaching is formulated around human existence, men, women, and children, with all their ups and downs, and the core of the lesson and the response expected are topics that still apply to our students today. Like Jesus, we can apply care in our teaching, like him we are not to discriminate against our students, and we can reach out to those who have certain difficulties. As teachers, we need to set time aside for every one of our students and strive to understand what misfortunes they are dealing with.

Jesus' parables are short and concise, marked by simplicity and symmetry, focused on people, include fictional descriptions applicable to everyday life, inclusive, often contain a reversal, they are contextual, theocentric, and with a key ending (Snodgrass 2008, 17). We can state that his teachings were holistic because his listeners adopted knowledge by which they could understand the world around them. In the contemporary context, in the process of upbringing and education, we can give our students access to teaching content that will reflect such a holistic understanding of the world.

In his constructivist approach to the learning process, Jesus encouraged active student participation, offered instruction that was related to their interests and learning style, and certainly improved their learning. The constructivist approach is not superior to the traditional one and has its limitations in neglecting the culture of the school and the wider social environment in the learning process (Jukić 2013, 244). It is considered a theory of learning, not part of the didactics implemented in teaching. The approach relies on the individualization of constructive learning with a reduced teaching role, but with many possibilities of connecting 
the content of other areas and everyday life. Precisely in today's circumstances, forced globally into distance learning systems, we expect from our student's individualization in learning, and a constructive character and autonomy in learning. As constructivist teachers, we can encourage and expect student independence and initiative, motivate students to use the variety of learning materials available in the digital world, test students' understanding before giving our interpretation, encourage open questions, conversation, and discussion, and place students in experiences which are contradictory to their previous understanding, in a motivating and playful atmosphere (Brooks and Brooks 1993, 109).

As for some practical guidelines for organizing online classes, Gewin (2020, 295) suggests that each lesson be limited to 40 minutes, while the essence of multihour teaching can be summarized in a video presentation of no more than 30 minutes, warning that students are reluctant to watch content without the voice and character of the teacher. And the tasks assigned to students are most effectively performed within 30 minutes, which is in line with the Recommendations on the organization of students' working days during distance learning (Ministry of Science and Education, 2020, 7). Furthermore, Zheng and Zhu $(2020,12)$ conclude from research that the most effective ways to teach practical aspects are to watch videos of certain skills and to independently record and analyze these skills.

\section{Conclusion}

In contemporary circumstances where schools are forced to move away from their traditional didactic approaches, we seek as teachers to extract those characteristics and practical advice from the way Jesus taught and apply them in today's process of upbringing and education. Jesus was a different teacher, an innovative methodologist, ahead of his time, and with his methods, he knew how to intrigue listeners and encourage them to actively learn and put their knowledge into practice. In his approach, he used, in contemporary terminology - constructivist paradigms, in which his listeners represent the subject of the teaching process. He knew that their learning depended on their prior knowledge and that they would be able to adopt the new concepts he presented to them by changing the old ones, meanwhile not wanting them only accumulating new information, but meaningfully changing old attitudes and drawing new conclusions. Their learning was influenced by the context in which they were taught, and they were required to be involved, to explore and reflect on what is being learned, through provocative challenges of everyday problems whose solution offers the interpretation of new knowledge, and to ultimately be evaluated.

This short article provides only a foretaste of concepts, approaches, and content that different authors carefully research and deepen while they discover disagreements with other authors. Jesus' parables are the subject of many authors, 
with varied interpretations and proposed applications. Also, the constructivist approach to the learning process encounters deep discussions and different directions, as well as the conflicting views of more conservative Christian teachers (Roso 2010,3). Distance learning is one of the concepts in the sea of virtual names for such teaching and has behind itself the whole theory and explanation of the model within the approach. These are all guidelines for possible further research and narrowing of the area of research interest.

It is up to us teachers to reflect on the approach Jesus used and strive to be like him as much as possible in our efforts to impart knowledge, skills, abilities, and values. Like the example, Jesus gives us, in our didactic approach we can try to recognize the student's experiences as a valuable individual reality, and use them in connecting teaching content. We can approach our students with the character that Jesus had - with love and respect, to encourage and guide them, to animate and change old conceptions, with new, valuable, and eternal ones.

\section{References}

Bailey, Kenneth E. 1983. Poet and Peasant and Through Peasant Eyes: A LiteraryCultural Approach to the Parables of Luke. Grand Rapids: Eerdmans.

Bonk, Curtis Jay and Vanessa Dennen. 1999. "Teaching on the Web: With a Little Help from My Pedagogical Friends." Journal of Computing in Higher Education, 11 (1): 3-28.

Breech, James. 1989. Jesus and Postmodernism. Minneapolis: Fortress Press.

Brooks, J. G., and M. G. Brooks. 1993. In Search of Understanding: The Case for Constructivist Classrooms. Alexandria: Association for Supervision and Curriculum Development.

Fitzpatrick, N., Nóirín Hayes, and K. C. O’Rourke. 2009. “Beyond Constriction and Control: Constructivism in Online Theory and Practice." In: C. R. Payne, ed. Information Teciihnology and Constructivism in Higher Education: Progressive Learning Frameworks, 14-26. Hershey: IGI Global.

Garrison, R. 2009. "Implications of online learning for the conceptual development and practice of distance education." Journal of Distance Education 23 (2): 93-104.

Gewin, V. 2020. "Five tips for moving teaching online as COVID-19 takes hold." Nature 580: 295-96.

Hultgren, Arland J. 2000. The Parables of Jesus: A Commentary. Grand Rapids: William B. Eerdmans Publishing Company.

Hunter, A. M. 1979. The Parables Then and Now. London: SCM Press Ltd. 
Jeremias, Joachim. 1972. The Parables of Jesus. New York: Charles Scribner's Sons.

Jones, Peter Rhea. 1999. Studying the Parables of Jesus. Macon: Smyth \& Helwys Publishing, Inc.

Jukić, R. 2013. „Konstruktivizam kao poveznica poučavanja sadržaja prirodoznanstvenih i društvenih predmeta“. Pedagogijska istraživanja, 10 (2): 241-63.

Katavić, Ivica, Dimitrije Milojević, and Mario Šimunković. 2018. „Izazovi i perspektive online obrazovanja u Republici Hrvatskoj“. Obrazovanje za poduzetništvo 8 (1): 95-107.

Lambrecht, Jan. 1974. “The Message of the Good Samaritan." Louvain Studies 5: 121-35.

Lee, Kyungmee. 2017. "Rethinking the accessibility of online higher education: A historical review." Internet and Higher Education 33: 15-23.

Means, Barbara, Yukie Toyama, Robert Murphy, Marianne Bakia, and Karla Jones. 2009. Evaluation of Evidence-Based Practices in Online Learning: A Meta-Analysis and Review of Online-Learning Studies. Washington, D.C.: US Department of Education.

Ministarstvo znanosti i obrazovanja u RH. 2020. Preporuke o organizaciji radnoga dana učenika tijekom održavanja nastave na daljinu. Zagreb.

Porton, Gary G. 2006. "The Parable in the Hebrew Bible and Rabbinic Literature." In: Levine, Amy-Jill, Dale C. Allison Jr, and John Dominic Crossan, eds. The Historical Jesus - in Context, 206-21. Princeton: Princeton Readings in Religions.

Robertson, William H. 2008. "The Greatest Constructivist Educator Ever: The Pedagogy of Jesus Christ in the Gospel of Matthew in the Context of the 5Es." Christian Perspectives in Education 1 (2): 1-17.

Roso, Calvin G. 2010. “Constructivism in the Classroom: Is It Biblical?" In: HeeKap Lee, ed. Faith-Based Education That Constructs, 38-45. Eugene: Wipf and Stock Publishers.

Schottroff, Luise. 2006. The Parables of Jesus. Minneapolis: Fortress Press.

Snodgrass, Klyne. 2008. Stories with Intent: A Comprehensive Guide to the Parables of Jesus. Grand Rapids: William B. Eerdmans Publishing Company.

Stein, Robert H. 1978. The Method and Message of Jesus' Teachings. Philadelphia: The Westminster Press.

Swan, K. 2005. "A constructivist model for thinking about learning online." In: J. Bourne and J. C. Moore, eds. Elements of Quality Online Education: Engaging Communities, 1-19. Needham, MA: Sloan-C. 
Swan, K., Garrison, D. R., and Richardson, J. C. 2009. "A constructivist approach to online learning: the Community of Inquiry framework." In: C. R. Payne, ed. Information Technology and Constructivism in Higher Education: Progressive Learning Frameworks, 43-57. Hershey: IGI Global.

Zheng, T., and Xinhong Zhu. 2020. "Comparing the effects of online teaching during the COVID-19 pandemic and traditional teaching in Surgical Nursing" [preprint]. https://www.researchgate.net/publication/347005974_ Comparing_the_effects_of_online_teaching_during_the_COVID-19_ pandemic_and_traditional_teaching_in_Surgical_Nursing (accessed Febru-ary 25, 2021).

\section{Maja Seguin}

\section{Što bi Isus učinio u modelu poučavanja na daljinu?}

\section{Sažetak}

Uslijed prelaska s tradicionalnog na virtualno poučavanje, nastaju razna pedagoška preispitivanja te je nužno omogućiti učiteljima primjer pristupa poučavanju i učenju. Ovaj članak daje pregled modela poučavanja koji je Isus koristio, posebice prispodobe ili parabole, ističe model suvremenog konstruktivističkog poučavanja te izdvaja karakteristike konstruktivizma u Isusovom modelu. Sve to predstavlja osnovu za praktične savjete u današnjem kontekstu poučavanja na daljinu, odnosno u virtualnom kontekstu. Članak izdvaja karakteristike Isusa kao učitelja koje suvremeni učitelji mogu preslikati u svom kontekstu, te završava sa smjernicama za daljnja moguća područja istraživanja. 